\title{
INTEGRASI UNSUR SPIRITUALITAS DALAM PRINSIP GOOD COOPERATIVE GOVERNANCE: REVITALISASI NILAI KOPERASI
}

\author{
Fitri Nur Rilah dan Nur Indah Riwajanti \\ Program Studi Akuntansi Manajemen, Politeknik Negeri Malang \\ Email: fitrinur.rilah96@gmail.com dan nurindah12@gmail.com
}

\begin{abstract}
The aim of this research was to examine the integration of spirituality element in Good Cooperative Governance (GCG) priciples. This was a qualitative postmodernist research. The research was conducted in one of small towns in East Java often called 'Kota Santri/Islamic Student City', namely Pasuruan City. The informants in this research were Head of Empowerment Section and Head of Institutional Section in Department of Cooperative and SMEs of Pasuruan; Cooperative Board and Manager in one of the cooperative in Pasuruan. Data collection was conducted with in-depth interview. The data used was primary data as qualitative data. Thematic analysis was used as analysis technique. The qualitative information was coded (translated) into qualitative data; followed by arrangement of pattern/theme; then encoding process (classifying pattern/theme into the relationships between categories); defining and describing the categories; and the last conclusion drawing. The result indicates that GCG has the uniqueness that enables its principles integrated of spirituality element. The essence of the spirituality value is cooperative values and its embodiment as an effort to revitalyze the cooperative values. The finding of this research was Fishbone Diagram of Spirituality Values on GCG Principles.
\end{abstract}

Keywords: Cooperative Values, Good Cooperative Governance, Revitalization, Spirituality.

\section{PENDAHULUAN}

Berawal dari istilah "Koperasi sebagai Soko Guru Perkenomian Indonesia”, mengingatkan kepada sosok Bapak Koperasi Indonesia, Moh. Hatta, seorang ahli ekonomi yang memiliki suatu konsep pemikiran unggul mengenai koperasi. Beliau menyatakan bahwa "ekonomi kerakyatanlah yang bisa mensejahterakan rakyat Indonesia". Pernyataan Bung Hatta ini menegaskan koperasi sebagai pilar atau penyangga utama perekonomian. Sistem perekonomian di Indonesia juga secara khusus diatur dalam UUD 1945 Bab XIV mengenai Perekonomian Nasional dan Kesejahteraan Sosial. Dalam UUD 1945 Bab XIV tepatnya pasal 33 ayat 1 disebutkan bahwa perekonomian disusun sebagai usaha bersama atas asas kekeluargaan. Badan usaha yang memenuhi kriteria seperti disebutkan di atas adalah koperasi.

Namun, tampaknya dewasa ini mengindikasikan mulai memudarnya eksistensi koperasi sebagai salah satu pilar perekonomian nasional. Hal ini direpresentasikan dengan koperasi yang serasa terlindas oleh lembaga 
keuangan lain yang sedang gencar dengan sistem komersialisasi dalam globalisasi. Di samping itu didukung pernyataan OJK Malang yang mengeluarkan himbauan agar masyarakat mewaspadai dan berhati-hati terhadap koperasi yang berlabel dan berpraktik seperti bank (Ucu, 2016). Fenomenanya, nama koperasi hanya dijadikan label bagi lembaga keuangan yang sesungguhnya cenderung 'mencekik' masyarakat kecil dengan tingginya bunga pinjaman dan pembagian Sisa Hasil Usaha (SHU) yang tidak transparan dan tidak merata. Hal inilah yang menjadi penyebab memudarnya makna koperasi sebagai soko guru perekonomian nasional.

Selain masalah komersialisasi, banyak koperasi yang belum menerapkan tata kelola koperasi yang baik yang dikenal dengan istilah Good Cooperative Governance (GCG), atau bahkan belum mengenal istilah tersebut. Rendahnya tata kelola dalam usaha berbentuk koperasi menimbulkan kesangsian atas kerelevansian koperasi dewasa ini. Misi dari penerapan Good Cooperative Governance adalah membidik pelaku dan sistem pada suatu gerakan koperasi untuk mewujudkan Good Person dan Good System dalam agency relationship.

Agency relationship ini membedakan antara pengurus koperasi yang dibantu oleh pengelola dikatakan sebagai agent, sementara anggota koperasi merupakan principal. Dalam hal ini, sektor ekonomi kecil dan mikro (seperti koperasi) membutuhkan bantuan dalam aspek governance dan transparansi untuk berkembang lebih baik lagi. Untuk itu, adanya terapi spiritulitas diharapkan bisa meminimalkan agency problem yang ada dalam hubungan muamalah (DEKS - BI; Prodi Ekonomi Islam FEB Unpad, 2016). DEKS BI dan Prodi Ekonomi Islam FEB Unpad (2016) menyebutkan bahwa inti dari spiritualitas adalah meaning of life and values. Masih dalam telaah spiritualitas, Suryaningrum (2011) juga mengatakan bahwa dalam akuntansi kontemporer sikap sosio-spiritualitas menjadi suatu tantangan. Didukung dengan dua pemikiran tersebut, penelitian ini berfokus terhadap penerapan prinsip GCG dalam bingkai spiritualitas.

Lebih lanjut, temuan Prasetyo (2012) menyebutkan bahwa GCG memoderasi hubungan kinerja keuangan dengan nilai spiritualitas pribadi. Di samping itu, pada tahun 2015 Kuncoro memfokuskan penelitiannya pada akuntansi pertanggungjawaban sosial Islami pada sebuah Koperasi Jasa Keuangan Syariah (BMT) UGT Sidogiri Pasuruan. BMT ini merupakan salah satu BMT yang bersifat ikonik di Pasuruan.

Jika melihat pada penelitian-penelitian sebelumnya, belum ada penelitian yang fokus pada penerapan prinsip GCG di koperasi dan integrasi unsur spiritualitasnya. Oleh karena itu, menjadi menarik untuk menganalisis prinsip GCG dan mengungkap nilai-nilai yang ada di dalamnya. Tujuan penelitian ini adalah Untuk mengetahui integrasi unsur spiritualitas dalam penerapan prinsip Good Cooperative Governance sebagai wujud revitalisasi nilai koperasi. 
Pengertian koperasi dirujuk dari UU No. 25 tahun 1992 tentang Perkoperasian sebagaimana dimaksud di bawah ini:

Koperasi adalah badan usaha yang beranggotakan orang-seorang atau badan hukum koperasi dengan melandaskan kegiatannya berdasarkan prinsip koperasi sekaligus sebagai gerakan ekonomi rakyat yang berdasar atas asas kekeluargaaan (pasal 1 (1)).

Agar koperasi tidak mati dalam membangun sistem ekonomi kerakyatan, maka diperlukan adanya revitalisasi nilai-nilai koperasi dan menerjemahkan pengertian koperasi itu sendiri. Sartono (2010) mengatakan bahwa revitalisasi koperasi adalah mengembalikan kekuatan (tenaga) kaidah koperasi sebagai kekuatan ekonomi kerakyatan. Hal ini dilakukan untuk mencapai tujuan mulia koperasi, demi kepentingan anggota dan kepentingan rakyat.

Lantas, apakah diperlukan penerapan GCG (Good Cooperative Governance)? Koperasi merupakan badan usaha yang dijalankan bersama dengan asas kekeluargaan dan tidak semata-semata profit oriented, namun berorientasi mensejahterakan anggota dan masyarakat umum. Gerakan koperasi merupakan keseluruhan perangkat organisasi beserta kegiatan yang terkait perkoperasian untuk mewujudkan cita-cita bersama dan tujuan mulia koperasi (pasal 1 (5) UU No. 25/1992). Koperasi juga memiliki organ koperasi yang terdiri dari pengurus, pengelola, pengawas, dan Rapat Anggota (RA) sebagai pemegang kekuasaan tertinggi. Oleh karena itu, diperlukan tata kelola koperasi yang baik.

Banco Central do Brasil (dalam bahasa Portugis) atau Bank Sentral Brazil (2008) dalam buku terbitannya (Cooperative Governance: Guidlines for Good Practice of Financial Cooperative Governance) mengungkapkan pengertian Cooperative Governance, yaitu:

A set of internal and external mechanisms and controls enabling the members to define and ensure attainment of cooperative ob-jecetives, securing their continuity and cooperative priciples.

Pengertian tersebut menguraikan bahwa Good Cooperative Governance adalah seperangkat peraturan baik internal maupun eksternal dan pengendalian terhadap anggota untuk mendefinisikan dan memastikan pencapaian tujuan, kontinuitas, dan prinsip koperasi. Dalam konsep GCG terdapat prinsip-prinsip GCG yaitu prinsip TARIF yang diuraikan di bawah ini dengan merujuk pendapat Kemenkop (2016): 1) Transparency (Keterbukaan), 2) Accountability (Pertanggungjawaban), 3) Responsibility (Kepatuhan), 4) Independency (Kemandirian), Fairness (Adil dan Merata).

Selanjutnya, akan dibahas teori yang terkait dengan good governance, yaitu agency theory. Terdapat pola hubungan dua pihak di dalam agency theory: principal dan agent. Pihak pertama yang memberi kontrak disebut "pricipal", dan pihak kedua yang menerima kontrak disebut "agent" (DEKS BI; Prodi Ekonomi Islam FEB Unpad, 2016). Principal mengamanahkan perusahaan/project atau sejenisnya kepada agent dalam suatu kontrak.

Terdapat pula etika dalam hubungan principal dan agent. Berkaitan dengan etika, spiritualitas mampu mengarahkan pada perilaku yang baik. 
Spiritualitas tidak dapat dipisahkan dari agama (Rahayuningsih, 2012). Senada dengan komentar tersebut, Triyuwono (2015) menyebutkan teori etika yang bersumber dari agama:

Agama, dalam teori etika ini, merupakan sumber yang dapat dijadikan sebagai pedoman untuk mengetahui atau membedakan yang baik dari yang buruk dan yang benar dari yang salah. Mengapa agama dijadikan sumber nilai? Karena hanya Tuhanlah yang memiliki otoritas tertinggi dalam menetapkan nilai-nilai yang baik dan yang benar.

Jadi, dimensi spiritualitas dalam etika dan agama saling berkaitan. Hal ini dikarenakan adanya virtue ethics (etika kebajikan) yang berdasarkan pada keyakinan (belief).

Pada perspektif semua penganut agama, Teori Etika Teonom mengatakan bahwa karakter moral manusia ditentukan secara hakiki oleh kesesuaian hubungannya dengan kehendak Allah (Agoes \& Ardana, 2011). Teori ini seperti ajaran dalam Agama Islam. Berkaca pada teori-teori etika tersebut, maka sangatlah mungkin jika akuntansi dikatakan sebagai ideologi.

Riahi dan Belkaoui (2006) telah mengemukan hakikat akuntansi sebagai ideologi, bahwa akuntansi dipandang sebagai suatu fenomena ideologi sebagai sarana untuk mempertahankan dan melegitimasi aturanaturan sosial, ekonomi dan politik yang berlaku saat ini. Maka dari itu, etika dalam akuntansi sangat diperlukan sebagai batasan untuk bertindak.

\section{METODE PENELITIAN}

Penelitian ini merupakan penelitian kualitatif dengan paradigma postmodernist. Penelitian ini dilakukan di salah satu kota kecil di Jawa Timur yang kerap disapa 'Kota Santri', yaitu kota Pasuruan. Penelitian ini menggunakan sumber data primer berupa data kualitatif (kutipan wawancara). Wawancara mendalam merupakan instrumen pengumpulan data. Adapun sumber informasi yang digunakan yaitu:

1. Kepala Sie Pemberdayaan Koperasi (selanjutnya disebut Kasie Pemberdayaan) dan Kepala Sie Kelembagaan Koperasi (selanjutnya disebut Kasie Kelembagaan) - Dinas Koperasi dan UKM Kota Pasuruan

2. Pengurus di salah satu koperasi simpan pinjam di Pasuruan.

3. Pengelola di salah satu koperasi simpan pinjam di Pasuruan.

Analisis data menggunakan teknik thematic analysis (analisis tematik). Proses analisis memungkinkan penerjemahan (coding) informasi kualitatif dari informan menjadi data kualitatif. Teknik ini menghasilkan suatu temuan pola yang hanya ditemukan oleh peneliti sebagai human instrument dalam penelitian kualitatif. Berikut gambar kerangka penelitian ini:

Gambar 1. Kerangka Penelitian

Prinsip Good Cooperative Governance dan Aspek Spiritualitas
Topik Penelitian 


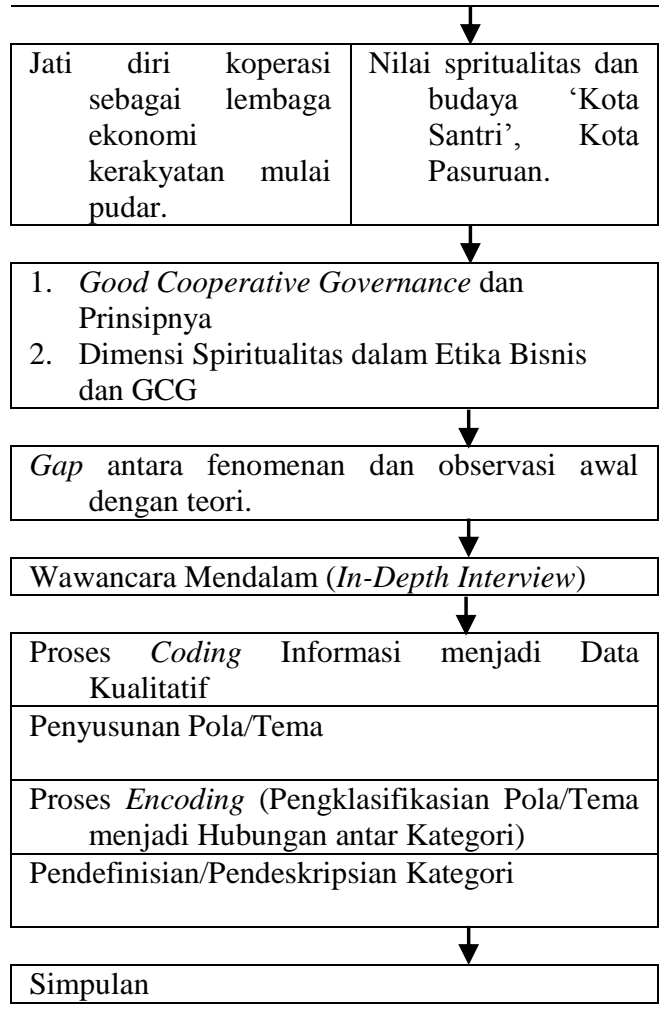
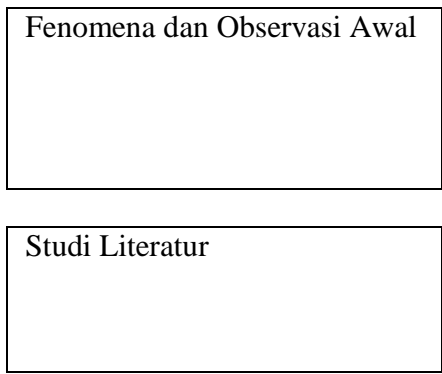

Fokus Masalah dan Tujuan
Penelitian

Pengumpulan Data

\begin{tabular}{|l|}
\hline $\begin{array}{l}\text { Analisis Tematik - Mereduksi } \\
\text { Data }\end{array}$ \\
\hline Analisis Tematik - Penyajian \\
Data \\
\hline $\begin{array}{l}\text { Analisis Tematik - Penyajian } \\
\text { Data }\end{array}$ \\
\hline $\begin{array}{l}\text { Analisis Tematik - Penyajian } \\
\text { Data }\end{array}$ \\
\hline
\end{tabular}

Penarikan Simpulan

\section{HASIL DAN PEMBAHASAN}

Sebelum menyelami bagian ini lebih dalam, akan didahului dengan suatu pengantar bahwa untuk mencapai keselarasan tujuan pelaksanaan UU 25/1992 secara murni oleh gerakan koperasi, peran Dinas Koperasi dan Dewan Koperasi Indonesia Daerah (Dekopinda) harus berjalan seimbang dan beriringan. Dekopin mengenalkan Ideologi Koperasi menuju tata kelola koperasi yang baik (Good Cooperative Governance). Kasie Pemberdayaan menguraikan mengenai Ideologi Koperasi sebagai dasar pelaksanaan Good Cooperative Governance, sebagai berikut:

"Cooperative beda dengan corporate. ... Nilai-nilai koperasi, itu yang digali dari budaya Indonesia yah, seperti contohnya gotong royong, kemudian solidaritas, keadilan, kejujuran,... ada sepuluh, yang ke dua adalah emmm... pengertian tentang koperasi itu sendiri. Kemudian yang ke tiga adalah prinsip ko..perasi.. Nah kalau ini dilaksanakan, sesungguhnya sudah orientasinya itu. Kemudian masuk pada tatanan.. eee.. good.. Good Cooperative Governance” 
Kasie Pemberdayaan di atas menyebut ideologi koperasi sebagai wujud kristalisasi dari nilai-nilai koperasi, pengertian koperasi dan prinsip koperasi. Jelas disebutkan bahwa ketiga komponen itu dikolaborasikan membentuk suatu komitmen 'cantik' sebagai upaya melaksanakan kebijakan dalam pembangunan koperasi. Ideologi koperasi inilah yang menjadikan koperasi memiliki ciri khas tersendiri dibandingkan dengan korporat.

Nilai-nilai koperasi ini bersumber dari budaya Indonesia yang terdiri dari 10 nilai yaitu: 1) menolong diri sendiri; 2) tanggung jawab; 3) demokratis; 4) kesetaraan; 5) keadilan; 6) solidaritas; 7) kejujuran; 8) keterbukaan; 9) tanggung jawab sosial; dan 10) kepedulian terhadap orang lain. Kemudian ada jati diri koperasi yang tertuang dalam pasal 1 sampai 5 UU 25/1992. Pengertian koperasi masuk dalam jati diri koperasi pasal 1, diikuti dengan pelengkapnya sampai pasal 4. Pasal 5 UU/1992 menyebutkan tentang prinsip koperasi. Ideologi koperasi ini ada di dalam upaya menerjemahkan UU 25/1992 dan harus dilaksanakan untuk mencapai Good Cooperative Governance.

Selain ideologi koperasi, dengan maksud mendukung pernyataan Kasie Pemberdayaan, kutipan di bawah ini disampaikan oleh Kasie Kelembagaan:

"Sama tata kelolanya.. cuma koperasi itu kan ada nilai-nilai dan jati diri koperasi, itu yang membedakan dengan perusahaan. Koperasi memiliki asas, ya prinsipnya ada, iya kan. Asasnya kegotongroyongan, kebersamaan.."

Kutipan singkat di atas menggaris bawahi satu hal lagi yang unik dalam Good Coooperative Governance yaitu asas koperasi. Seperti yang disebutkan di atas yaitu asas kegotong-royongan, kebersamaan, dan asas yang lain.

Lebih lanjut, jika berbicara mengenai spiritualitas, pasti manusia sebagai fokus utamanya. Spiritualitas manusia akan diintepretasikan dalam perilaku (human behaviour). Senada dengan yang disampaikan oleh Kasie Pemberdayaan sebagai pembuka:

“... kalau aturannya itu kan ya udah paten kan? ... Yang perlu ditembak itu SDMnya. Kalau bagus InsyaAllah, input bagus, proses juga bagus. Karena kecenderungan yang namanya spiritualitas itu adalah [pause] pelaku.. Jadi, Koperasi itu ndak pernah lepas dari kristalisasi, 3 komponen tadi. Nah kalau itu tumbuh dengan bagus, itu sesungguhnya, apa yang disampaikan dengan spiritualitas dan sebagainya itu, itu tercermin di dalamnya. Saya yaaakin itu [dengan penuh keyakinan]..

Karena apa, harapan-harapan dalam nilai-nilai itu, sudah disalurkan di [pause] dalam wujud ya. Jadi, misalnya cerita kejujuran, tentang kejujuran saja. Kita transparansi laporan itu, kejujuran.."

Jelas disampaikan di atas, pelakulah yang dibidik untuk mampu ditanamkan nilai-nilai spiritualitas, sehinggga tercermin dalam perilakunya. 
Perilaku organ koperasi harus berdasar pada ideologi koperasi, karena di dalam ideologi koperasi tercermin nilai-nilai spiritualitas. Dengan refleksi nilai-nilai spiritualitas ini sesungguhnya menyeimbangkan antara pola hubungan vertikal dengan Sang Pencita (Habblum Minallah) dan pola hubungan horizontal (Hablum Minannaas). Pada hakekatnya, jika menguraikan tentang penerapan prinsip GCG, pasti ada pelaku di dalamnya, yaitu organ koperasi. Jadi, antara agent dan principal terlebih dahulu harus memahami karakteristik koperasi. Teori Good Cooperative Governance merupakan bentuk perkembangan dari teori Good Corporate Governance.

Dalam uraian singkat di atas telah disinggung sedikit mengenai adanya nilai-nilai spiritualitas dalam penerapan prinsip GCG. Lebih lanjut, Kasie Pemberdayaan mengutarkan:

“... jadi koperasi itu semuaaanya yang baik.. Dari nilai-nilai tadi itu, dari 10 nilai, itu semuanya masuk. Jadi, mulia sekali kalau spiritualitas itu memasang spiritual tadi masuk dalam koperasi, dan memang koperasi itu sesungguhnya kalau dilibatkan dengan jati diri itu, kemaslahatan dunia akhirat itu memang.. sejahtera itu sama dengan salam. "Assalaamu'alaikum”, salam itu sama dengan kesejahteraan dunia akhirat. Tidak hanya keselamatan saja, keselamatan yang plus. Itu tujuan mulia.."

Jika menyimak kutipan di atas, nilai-nilai spiritualitas yang direfleksikan ke dalam penerapan prinsip GCG erat kaitannya dengan 10 nilai koperasi. Artinya, nilai spiritualitas dalam penerapan prinsip GCG tercermin dalam nilai-nilai koperasi. Perwujudan nilai-nilai ini bertujuan untuk mencapai tujuan koperasi yaitu mensejahterakan anggota dan masyarakat. Jika dimaknai dengan seksama, tujuan ini berorientasi untuk kemaslahatan fiddunya wal aakhiroh (dunia dan akhirat).

Pendapat senada direkam dari beberapa informan yang berkecimpung langsung dalam kepengurusan koperasi. "Zakat itu biar selamet semua [sembari tersenyum]", ungkap Pengurus koperasi. Orientasi vertikal dalam metafora zakat yang bersifat ideografik (lokal dan unik) inilah yang tampak abstrak dan tidak bisa diukur dengan indikator apapun. Pada intinya, kesejahteraan (keselamatan) yang ingin dicapai bermuara pada keselamatan akhirat dan berorientasi pada keberkahan seperti yang disampaikan Pengelola di bawah ini:

"Iyah... barokahnya orang-orang sini, doanya orang-orang ini (dari zakat itu mbak) [nampak merendah]. Sini religi semua orangnya mbak. Sing penting ingin berbuat baik - berbuat baik, urusannya sama yang di atas, [sembari menunjuk yang Maha Kuasa].."

Lebih lanjut, koperasi juga memiliki hal-hal yang bersifat ideografik dan terdapat refleksi nilai-nilai spiritualitas. Berikut akandijelaskan alur analisis sampai menuju pada refleksi nilai-nilai spiritualitas pada penerapan prinsip GCG. Dalam skema tersebut, nampak bahwa refleksi nilai 
spiritualitas menjadi muara analisis, yaitu analisis yang paling dalam terhadap 'nilai lain' yang dianggap penting.

Gambar 2. Alur Analisis Nilai Spiritualitas dalam Penerapan Prinsip GCG
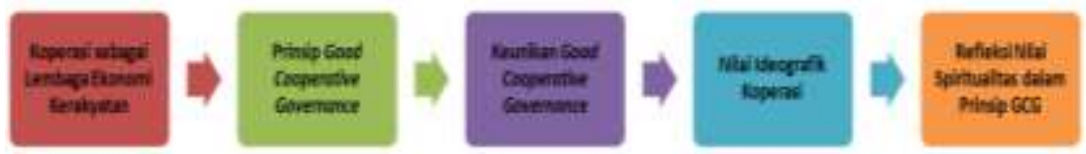

Pada hasil analisis telah sedikit disinggung bahwa 'nilai lain' yang terefleksi dalam prinsip GCG berupa nilai spiritualitas dan kearifan lokal warga Pasuruan yang menjustifikasi wilayahnya sebagai 'Kota Santri'. Pada Gambar 2, skema refleksi nilai spiritualitas menunjukkan pola penerapan prinsip GCG menuju pada keunikan Good Cooperative Governance.

Tabel 1. Keunikan Good Cooperative Governance

\begin{tabular}{clll}
\hline No. & \multicolumn{1}{c}{ Aspek } & \multicolumn{1}{c}{$\begin{array}{c}\text { Good Cooperative } \\
\text { Governance }\end{array}$} & \multicolumn{1}{c}{$\begin{array}{c}\text { Good Corporate } \\
\text { Governance }\end{array}$} \\
\hline 1. & $\begin{array}{l}\text { Dasar } \\
\text { Komitmen }\end{array}$ & Ideologi Koperasi & Based on Capital \\
\hline 2. & $\begin{array}{l}\text { Asas } \\
\text { Pengelolaan }\end{array}$ & $\begin{array}{l}\text { Asas Kekeluargaan/ } \\
\text { Asas Koperasi }\end{array}$ & Prinsip Korporasi \\
\hline 3. & $\begin{array}{l}\text { Sistem Tata } \\
\text { Kelola }\end{array}$ & Fleksibel (buttom-up) & $\begin{array}{l}\text { Orientasi pemegang } \\
\text { saham (top-down) }\end{array}$ \\
\hline 4. & Pola Hak Suara & One member one vote & $\begin{array}{l}\text { Tergantung kepemili- } \\
\text { kan saham. }\end{array}$ \\
\hline
\end{tabular}

Sumber: data diolah

Tabel di atas telah menyajikan keunikan Good Cooperative Governance. Dari keunikan itulah, sistem berjalan fleksibel. Tidak heran apabila nilai spiritualitas dan nilai ideografik ada dalam prinsip GCG. Di bawah ini akan dibahas teori etika yang terkait nilai spiritualitas.

Teori etika yang bersumber dari agama menjadikan agama sebagai sumber nilai. Karena menjadi sumber nilai, maka kedudukan Sang Pencipta sebagai pemegang kekuasaan yang hakiki. Dalam teori ini mengandung nilai transendental, sehingga agama menjadi acuan. Agama Islam mengajarkan untuk berbuat kebaikan dan mengharapkan ridha Allah SWT. Dari sini, setiap tindakan yang dilakukan dipertanggungjawabkan kepada Allah SWT. Pertanggungjawaban vertikal inilah yang menyebabkan adanya rasa takut untuk mendustakan amanah, sehingga transformasi kesejahteraan berjalan.

Dari sudut pandang Agama (khususnya Agama Islam), zakat (seperti yang dikatakan Pengurus) merupakan suatu kewajiban pensucian harta seperti yang diatur dalam UU 23/2011 tentang Pengelolaan Zakat. Dalam prinsip GCG, zakat merupakan tanggung jawab sosial yang dibingkai dalam kearifan lokal (bersifat ideografk). Dengan berpedoman pada agama, mayoritas warga koperasi yang beragama Islam meyakini bahwa dengan pensucian harta inilah yang akan membawa keberkahan tersendiri baik bagi pelaku maupun bagi organisasi itu sendiri. Selain zakat, juga ada bentuk 
pendistribusian dana sosial dan pendampingan spiritualitas. Uraian-uraian di atas, merepresentasikan adanya etika yang bersumber dari agama.

Sebagaimana yang telah dikaji sebelumnya, beralih pada Teori Etika Teonom menekankan bahwa moral manusia akan berbanding lurus dengan hubungan kepada Sang Pencipta, Allah SWT. Teori ini lebih menekankan pada nilai spiritualitas yang sangat dalam. Dengan teori etika teonom, manusia akan memiliki moral baik karena memiliki hubungan dengan Allah SWT (Hablum Minallah). Hubungan vertikal ini, juga harus didampingi dengan hubungan horizontal (Hablum Minannaas).

Jika berkaca pada 2 teori di atas (teori etika yang bersumber dari agama dan teori etika teonom), maka ideologi pengelolaan koperasi mulai nampak. Pengelolaan koperasi tidak luput dari pengelolaan keuangan atau non keuangan. Suatu pola pertanggung-jawaban yang bermuara pada Pengurus sebagai wakil anggota, hendaknya mencerminkan 'nilai-nilai lain' yang dianggap penting tadi, yaitu nilai spiritualitas dan nilai ideografik. Sebagai sarana untuk menghasilkan laporan keuangan, teori akuntansi sebagai ideologi memandang akuntansi mampu mempertahankan aturanaturan yang berlaku, salah satunya aturan sosial. Produk yang dihasilkan juga harus mencerminkan aturan sosial. Dengan memiliki nilai ideografik dan nilai spiritualitas yang diwujudkan dalam nilai koperasi menstimulasi adanya bentuk pertanggungjawaban yang bernilai spiritualitas. Bentuk pertanggungjawaban merupakan akuntabilitas yang me-ngungkapkan zakat sebagai bentuk responsibilitas. Untuk mentransparansikan zakat, harus ada perlakuan akuntansi, yaitu adanya akuntansi pertanggungjawaban spiritualitas.

Gambar 3. Fishbone Diagram Nilai Spiritualitas pada Prinsip GCG

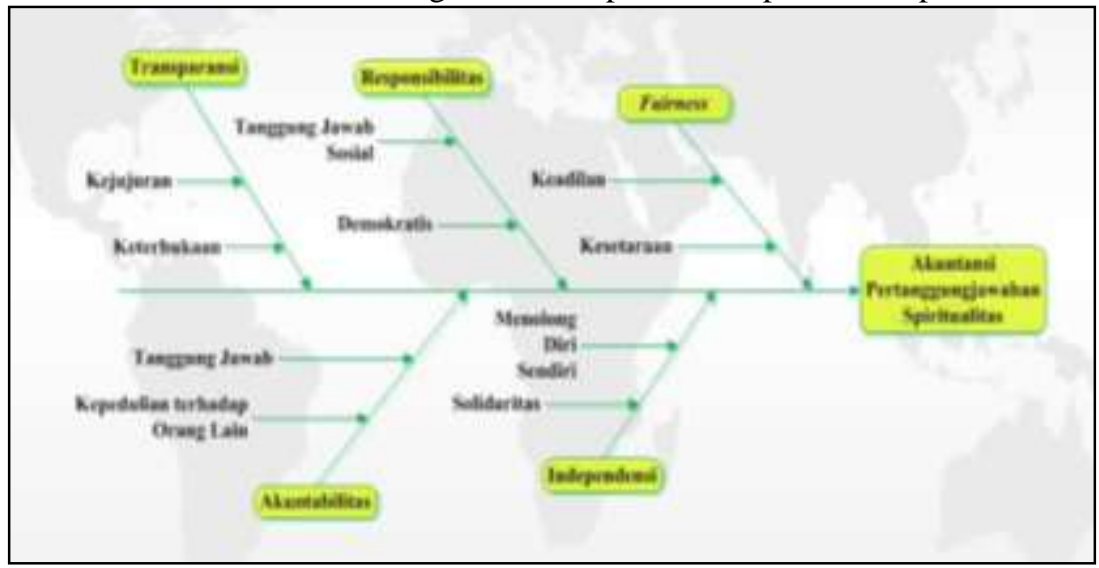

Selanjutnya, akan diuraikan lagi mengenai nilai spiritualitas yang diwujudkan dalam nilai koperasi dan diterapkan pada prinsip GCG. Refleksi nilai spiritualitas pada penerapan prinsip GCG akan disajikan dalam Fishbone Diagram (diagram tulang ikan). Diagram ini disebut juga diagram sebab akibat digunakan untuk meringkas adanya nilai spiritualitas yang dijabarkan dalam 10 nilai koperasi, kemudian nilai koperasi tersebut 
diwujudkan dalam penerapan prinsip GCG. Prinsip GCG diterapkan dalam akuntansi pertanggungjawaban yang bernilai spiritualitas. Dalam diagram ini, nilai koperasi diilustrasikan sebagai primary cause (sebab utama) yang menjadi dasar diterapkannya 5 kategori. Kategori ini merupakan kelima prinsip GCG. Perwujudan nilai koperasi dalam penerapan prinsip GCG ini menimbulkan adanya bentuk pertanggungjawaban yang diilustrasikan sebagai effect (akibat). Maka dari itu, akuntansi pertanggungjawaban spiritualitas itulah menjadi tujuan akhirnya sebagaimana disajikan dalam fishbone diagram diatas.

Pada diagram di atas ditunjukkan nilai-nilai koperasi yang diwujudkan dalam penerapan prinsip GCG. Di bawah ini akan di bahas masing-masing dari prinsip GCG beserta nilai-nilai yang ada di dalamnya:

\subsection{NILAI KEJUJURAN DAN KETERBUKAAN DALAM TRANSPARANSI}

Nilai kejujuran dan keterbukaan diwujudkan dalam penerapan prinsip transparansi. Prinsip transparansi yang terefleksi nilai spiritualitas diserukan pula dalam QS. Al-Ahzab (33:70):

"Wahai orang-orang yang beriman! Bertakwalah kamu kepada Allah dan ucapkanlah perkataan yang benar (QS. Al-Ahzab:70)"

Ayat tersebut menyerukan untuk bertakwa kepada Allah dan mengucapkan perkataan yang benar. Jika dikaitkan dengan pembukuan atau akuntansi, intinya semua proses pencatatan yang dilakukan harus merepresentasikan suatu kebenaran dan dilandasi dengan kejujuran. Pada akhirnya, hasil dari proses tadi ditransparansikan, sehingga tidak menimbulkan informasi yang tidak relevan. Nilai kejujuran dan keterbukaan juga berdasarkan pada asas keterbukaan.

\subsection{NILAI TANGGUNG JAWAB DAN KEPEDULIAN DALAM AKUNTABILITAS}

Tanggung jawab dan kepedulian merupakan nilai spiritualitas yang ada dalam diri individu untuk mampu melaksanakan tugas yang diembannya dengan tetap memperhati-kan kepentingan orang lain. Dalam firman Allah QS. Al-Mukminuun (23:8) disebutkan:

"dan (sungguh beruntung) orang yang memelihara amanat-amanat dan janjinya (QS. Al-Mukminuun:8)"

Sepenggal ayat Al-Qur'an ini menyeru untuk memelihara amanahamanah yang menjadi tanggung jawab diri sendiri. Disampaikan pula dalam ayat ini orang yang memelihara amanah niscaya akan diberkahi dengan keberuntungan. Nilai spiritualitas ini berdasarkan pada asas kebersamaan.

\subsection{NILAI TANGGUNG JAWAB SOSIAL DAN DEMOKRATIS DALAM RESPONSIBILITAS}

Nilai tanggung jawab sosial dimetaforakan dalam bentuk zakat dan Dana Sosial. Zakat dicadangkan berupa bentuk pensucian dari Jasa Anggota, Dana Pengurus dan Dana Karyawan yang merupakan bagian dari alokasi SHU. Zakat dikeluarkan setiap tahun setelah pengesahan dari RAT. Sedangkan 
Dana Sosial berupa shodaqoh merupakan alokasi dari SHU, dan ditransparansikan dalam Laporan Pembagian SHU.

Dengan adanya akuntansi pertanggungjawaban spiritualitas, pengungkapan zakat koperasi akan jelas. Hal ini memenuhi nilai demokratis yaitu dari, oleh dan untuk anggota. Dua nilai spiritualitas ini (tanggung jawab sosial dan demokratis) mendasarkan diri pada asas kekeluargaan.

\subsection{NILAI MENOLONG DIRI SENDIRI DAN SOLIDARITAS DALAM INDEPENDENSI}

Nilai spiritualitas yang tercermin dalam prinsip independensi adalah nilai menolong diri sendiri dan solidaritas. Nilai ini berdasarkan pada asas interdependensi, yaitu asas saling ketergantungan. Dikatakan saling ketergantungan karena adanya simbiosis mutualisme antara anggota sebagai principal dengan pengurus sebagai agent. Untuk memerdekakan diri sendiri dalam hal kemandirian, koperasi berupaya menghimpun anggota untuk menguatkan modal sendiri berupa simpanan pokok dan simpanan wajib. Hal ini juga berusaha untuk menghindari bentuk pinjaman dari pihak lain. Dengan kuatnya anggota, koperasi juga akan kuat, implikasinya anggota juga dapat memanfaatkan jasa koperasi. Di sinilah kekuatan solidaritas sangat berperan, sekaligus juga dalam proses pengambilan keputusan yang mengutamakan musyawarah.

Seruan untuk mewujudkan nilai spiritualitas yang satu ini ada dalam firman Allah QS. Asy-Syura (42:38) yang berbunyi:

"dan (bagi) orang-orang yang menerima (mematuhi) seruan Tuhan dan melaksanakan shalat, sedang urusan mereka (diputuskan) dengan musya-warah antara mereka; dan mereka menginfakkan sebagian dari rezeki yang Kami berikan kepada mereka (QS. AsySyura:38)"

Ayat di atas menyeru untuk memutuskan urusan dengan musyawarah, dan sekaligus menyeru untuk menginfakkan sebagian harta (rezeki) yang dimiliki. Kedua seruan tersebut diwujudkan dalam penerapan prinsip responsibilitas dan independensi. Penerapan prinsip ini bersumber dari akidah agama seperti yang telah dibahas dalam teori etika yang bersumber dari agama.

\subsection{NILAI KEADILAN DAN KESETARAAN DALAM FAIRNESS}

Koperasi memiliki asas kesetaraan dan persamaan. Asas inilah yang menjadi dasar perwujudan nilai keadilan dan kesetaraan dalam penerapan prinsip fairness. Keadilan dan kesetaraan berlaku pada semua organ koperasi. Perwujudan nilai ini yaitu dalam pembagian SHU yang dilakukan secara adil dan merata, serta tidak memandang organ koperasi berdasarkan kepentingan pribadi.

Nilai spiritualitas ini terkandung dalam firman Allah QS. Al-Ma'idah ayat 8 yang berbunyi:

"Wahai orang-orang yang beriman jadilah kamu sebagai penegak keadilan karena Allah, (ketika) menjadi saksi dengan adil. Dan janganlah kebencian-mu terhadap suatu kaum, mendorong kamu 
untuk berlaku tidak adil. Berlaku adillah, karena adil itu lebih dekat kepada takwa. Dan bertakwalah kepada Allah, sungguh, Allah Maha Teliti terhadap apa yang kamu kerjakan (QS. Al-Ma'idah:8)"

Dalam ayat di atas, disebutkan seruan untuk berlaku adil karena bertakwa kepada Allah dan menegakkan keadilan serta kesetaraan tanpa adanya benturan kepentingan. Nilai keadilan dan kesetaraan dalam nilai koperasi ini merupakan salah satu nilai spiritualitas yang memiliki pertanggungjawaban vertikal seperti dalam teori etika teonom.

Setelah sebelumnya diuraikan mengenai pembahasan tujuan penelitian, selanjutnya akan diuraikan implikasi penelitian, antara lain:

1. Implikasi Teoritis: Temuan penelitian terkait integrasi unsur spiritualitas dalam prinsip GCG yang berupa Fishbone Diagram Nilai Spiritualitas pada Prinsip GCG memberikan sumbangsih pada literasi tata kelola koperasi yang baik dengan perwujudan nilai-nilai koperasi. Di samping itu juga memberikan pengembangan dalam akuntansi koperasi agar dilaksanakan dengan prinsip Good Cooperative Governance yang terintegrasi nilai spiritualitas (nilai koperasi) di samping prinsip koperasi.

2. Implikasi Praktis: Salah satu keunikan Good Cooperative Governance yaitu dalam aspek dasar komitmen yakni Ideologi Koperasi. Ideologi ini yang menonjolkan jati diri dan nilai koperasi, sehingga memungkinkan koperasi untuk merefleksikan 'nilai lain' yaitu nilai spiritualitas dan nilai ideografik (nilai yang bersifat lokal dan unik). Dengan perwujudan nilainilai tersebut, dapat menghidupkan kembali jati diri koperasi sebagai lembaga ekonomi kerakyatan (member-based institution).

\section{SIMPULAN}

Pada model Good Coooperative Governance, lapisan pondasi yang paling atas adalah asas koperasi, serta prinsip dan nilai koperasi. Keberadaan dua pondasi tersebut menjadikan keunikan tersendiri bagi cooperative dari 4 aspek, yaitu: dasar komitmen, asas pengelolaan, sistem tata kelola dan pola hak suara. Good Cooperative Governance lebih fleksibel dengan kepemilikian yang universal, anggota sebagai pemilik dan pengguna jasa koperasi (pasal 17 UU 25/1992). Inilah yang membedakan cooperative dengan corporate. Karena keunikannya inilah, dalam penerapan prinsipinya dapat terefleksi dengan 'nilai lain', yaitu nilai spiritualitas dan nilai ideografik (kearifan lokal wilayah setempat).

Nilai spiritualitas dan nilai ideografik ini dikemas dalam teori etika. Dalam hal ini teori etika yang terkait adalah teori etika yang bersumber dari agama dan teori etika teonom, sekaligus merujuk pada firman-firman Allah yang menyerukan pada nilai-nilai spiritualitas. Jika teori etika ini dijadikan dasar dalam pengelolaan koperasi yang notabene menghasilkan suatu bentuk pertanggungjawaban, maka teori akuntansi sebagai ideologi juga nampak.

Produk akuntansi berupa laporan keuangan, yaitu Laporan Pertanggungjawaban Pengurus kepada anggota. Dalam hal ini adalah bentuk 
pertanggungjawaban yang bernilai spiritualitas. Nilai spiritualitas menjelma dalam nilai-nilai koperasi. Perwujudan 10 nilai koperasi ini berdasarkan pada asas koperasi yang diterapkan dalam prinsip GCG. Sehingga, muncullah akuntansi pertanggungjawaban yang bernilai spiritualitas. Integrasi nilai spiritualitas (nilai koperasi) dalam penerapan prinsip GCG menuju akuntansi pertanggungjawaban spiritualitas merupakan suatu temuan yang diilustrasikan dalam Fishbone Diagram Nilai Spiritualitas pada Prinsip GCG.

\section{DAFTAR PUSTAKA}

Agoes, S., \& Ardana, I. C. (2011). Etika bisnis dan profesi: tantangan membangun manusia seutuhnya. Jakarta: Penerbit Salemba..

Banco Central Do Brazil. (2008). Cooperative Governance. Barsilia: Banco Central Do Brazil.

DEKS - BI; Prodi Ekonomi Islam FEB Unpad. (2016). Usaha Mikro Islami: Seri Ekonomi dan Keuangan Syariah. Jakarta: DEKS - BI.

Kementerian Koperasi dan UKM RI. (2016). Tata Kelola Koperasi yang Baik: Good Cooperative Governance. Jakarta: Deputi Bidang Kelembagaan Kementerian KUKM.

Prasetyo, W. (2012). Implementasi Kinerja Keuangan Terhadap Nilai Spiritualitas Pribadi. EKUITAS (Jurnal Ekonomi dan Keuangan), 16(3), 332-351.

Rahayuningsih, D. A. (2012). Spiritual Value: Apa dan Bagaimana (Kajian pada Perilaku Manusia, Lingkungan Kerja dan Mekanisme Akuntansi). Media Bisnis, 4(2), 20-27.

Riahi, A., \& Belkaoui. (2006). Accounting Theory - Teori Akuntansi. Jakarta: Salemba Empat.

Sartono, A. T. (2010). Revitalitasasi Kaidah Koperasi Dalam Sistem Ekonomi Kerakyatan. Masalah-Masalah Hukum, 39(3), 245-252.

Suryaningrum, D. H. (2011). Sikap Sosio-Spritual Dalam Akuntansi Kontemporer: Telaah, Tantangan Dan Imajinasi Diri. AKRUAL: Jurnal Akuntansi, 3(1). 38-57.

Triyuwono, I. (2015). Akuntansi Syariah: Perspektif, Metodologi, dan Teori. Depok: PT Rajagrafindo Persada.

Ucu, K. (2016, April 16). OJK: Waspada Rentenir Berkedok Koperasi, News Republika.co.id. Malang, Jawa Timur, Indonesia.

http://www.republika.co.id/berita/nasional/daerah/16/04/27/o69v5n282-ojkwaspada-rentenir-berkedok-koperasi

Undang-undang Dasar Republik Indonesia tahun 1945. 
Undang-undang Republik Indonesia Nomor 25 Tahun 1992 tentang Perkoperasian. (1992). Jakarta. 